\title{
АРХЕОЛОГИЯ
}

DOI: https://doi.org/10.15688/jvolsu4.2018.6.1

UDC 903.8

Submitted: 26.01 .18

LBC 63.4(2)

Accepted: 02.04 .18

\section{FINDS OF HUMAN BONES IN SETTLEMENTS OF THE SCYTHIAN TIME IN FOREST-STEPPE REGION OF T HE DON BASIN ${ }^{1}$}

\author{
Yuriy D. Razuvaev \\ Voronezh State Pedagogical University, Voronezh, Russian Federation
}

\begin{abstract}
Introduction. The paper analyzes the finds of separate human remains from the Scythian settlements of the $6^{\text {th }}-3^{\text {rd }}$ centuries $\mathrm{BC}$ in the forest-steppe zone of the Don basin. We present the report of the available materials and evaluate the degree of representativeness of possible interpretations. Methods. Nowadays we have data on eleven household sites with anthropological materials, which had not yet been properly interpreted. The hillfort in the city of Semiluki is among them, and it includes fifteen burials of adults and children most of which are collective. Skulls and other parts of skeletons were buried later in the majority of these complexes. Besides, the human remains mixed with animals' bones were found in a specially built cult construction as well as in six domestic holes. Fragments of a clay altar together with three skulls were found in the Kirovskoe hillfort. The skull in a congestion of animals' bones was found in the settlement near the Podgornoe village. The well with full and fragmented skeletons was investigated in the hillfort near the village Verkhnee Kazachye. In other settlements of the region, human bones were found in a layer and in domestic holes. Analysis. The materials considered in the paper have quite broad analogies all over foreststeppe Scythia. The obtained data show that manipulations with human bones were of great importance in postfuneral rites of the forest-steppe population of the Scythian era. The bones found in the Don settlements belonged to different individuals, men and women of various age. The archaeological context and the range don't allow to mark the finds as a result of cannibalism, military collisions, or sacrifices. Results. It is the most probable that the emergence of separate bones in settlements is connected with funeral rite of corpse exposure, which, along with other funeral ceremonies, was applied by settled population of the Don forest-steppe.
\end{abstract}

Key words: forest-steppe region of the Don basin, Scythian era, settlements, human bones, funeral rite of exposure.

Citation. Razuvaev Yu.D. Finds of Human Bones in Settlements of the Scythian Time in Forest-Steppe Region of the Don Basin. Vestnik Volgogradskogo gosudarstvennogo universiteta. Seriya 4, Istoriya. Regionovedenie. Mezhdunarodnye otnosheniya [Science Journal of Volgograd State University. History. Area Studies. International Relations], 2018, vol. 23, no. 6, pp. 6-17. (in Russian). DOI: https://doi.org/10.15688/jvolsu4.2018.6.1

Дата поступления статьи: 26.01 .18

ББК 63.4(2)

Дата принятия статьи: 02.04.18

\section{НАХОДКИ ЧЕЛОВЕЧЕСКИХ КОСТЕЙ Н НА ПОСЕЛЕНИЯХ СКИФСКОГО ВРЕМЕНИ В ЛЕСОСТЕПНОМ ПОДОНЬЕ \\ Юрий Дмитриевич Разуваев \\ Воронежский государственный педагогический университет, г. Воронеж, Российская Федерация}

Аннотация. В статье анализируются находки разрозненных человеческих останков, сделанные на поселениях VI-III вв. до н. э. в лесостепной части бассейна Дона. В ней представлена сводка имеющихся материалов и оценивается степень репрезентативности возможных интерпретаций. 
Сейчас известно одиннадцать бытовых памятников с антропологическими материалами, пока должным образом не интерпретированными. Среди них выделяется городище в г. Семилуки, где открыто пятнадцать преимущественно коллективных погребений взрослых и детей. В большинство из этих комплексов позднее были захоронены черепа и другие части скелетов. Кроме того, человеческие останки, перемешанные с костями животных, встречены в специально возведенной культовой постройке, а также в шести хозяйственных ямах. Обломки глиняного жертвенника вместе с тремя черепами обнаружены на Кировском городище. Череп в скоплении костей животных найден на поселении у с. Подгорное. На городище у с. Верхнее Казачье исследован колодец с полными и разрозненными костяками. На других поселениях региона кости людей размещались в слое и в ямах хозяйственного назначения. Рассматриваемые в статье материалы имеют довольно широкие аналогии во всей Лесостепной Скифии. Полученные данные показывают, что манипуляции с человеческими костями имели большое значение в постпогребальных ритуалах лесостепного населения скифской эпохи. Найденные на донских поселениях кости принадлежали разным индивидам, мужчинам и женщинам разнообразного возраста. Археологический контекст и ассортимент не позволяют объяснить находки каннибализмом или военными столкновениями, нет оснований считать их свидетельством жертвоприношений. Наиболее вероятно, что появление на поселениях разрозненных костей связано с погребальной практикой выставления трупов, которая, наряду с другими похоронными обрядами, применялась оседлым населением донской лесостепи.

Ключевые слова: лесостепное Подонье, скифская эпоха, поселения, человеческие кости, погребальный обряд выставления.

Цитирование. Разуваев Ю. Д. Находки человеческих костей на поселениях скифского времени в лесостепном Подонье // Вестник Волгоградского государственного университета. Серия 4, История. Регионоведение. Международные отношения. -2018. - Т. 23, № 6. - C. 6-17. - DOI: https://doi.org/10.15688/jvolsu4.2018.6.1

Введение. За полстолетия целенаправленного изучения поселений VI-III вв. дон. э. в северной части бассейна Дона получены разнообразные данные о бытовом и хозяйственном укладах жизни их обитателей $[12$, с. 9-89; 20], но среди находок есть такие, что пока не получили однозначной интерпретации. Это разрозненные человеческие останки, встречающиеся в культурном слое или в строительных сооружениях городищ и неукрепленных поселений ${ }^{2}$. Число пунктов, где они обнаружены, постоянно растет и уже достигло одиннадцати (рис. 1) ${ }^{3}$. На этих памятниках имеются культурные напластования разных исторических эпох, тем не менее соотнесение находок со скифским временем не вызывает сомнений. Во-первых, часть антропологических материалов, как было сказано, происходит из более-менее закрытых комплексов. Во-вторых, человеческие кости вообще не редкость для поселений по всей Лесостепной Скифии [26].

Памятники с такого рода находками распределены по всему донскому ареалу скифоидной культуры и составляют примерно четверть от числа поселений, подвергавшихся сколько-нибудь значимым раскопкам. Это обстоятельство побуждает отнестись к рассматриваемому явлению как к некоей зако- номерности, требующей удовлетворительного разъяснения.

В данной статье представлена сводка имеющихся на сегодня материалов вместе с общей оценкой степени убедительности их возможных интерпретаций. Более детальный анализ феномена - задача будущего исследования.

Методы. Первая из интересующих нас находок в Подонье была сделана, видимо, еще в начале прошлого века. На городище у с. Каменка при выборке известняка местные крестьяне откопали череп [32, с. 109]. Других костей, надо полагать, при нем не было: сообщалось лишь о сопутствовавших обломках керамики. Впрочем, уже в наше время на городище открыто и полное захоронение шестимесячного ребенка [1, с. 189].

В 1958 г. человеческий череп был обнаружен Воронежской лесостепной скифской экспедицией Института археологии на поселении 3 в урочище «Частые курганы» около с. Подгорное [5, л. 49, табл. XXIV, 1]. Он лежал вместе с костями животных и обломками лепных сосудов IV-III вв. до н. э., вероятно, в не углубленной в материк яме (рис. 2, 1). В отчете о раскопках П.Д. Либеров отметил, что эта находка «не поддается объяснению». 
Позднее, в 1965 г., та же экспедиция изучила небольшое всхолмление на территории Кировского городища IV-II вв. до н. э., расположенного у хут. Городище [6, л. 51-68]. Помимо многочисленных фрагментов керамики и костей животных, там были обнаружены три человеческих черепа и обломки глиняного жертвенника. Связав находку с человеческими жертвоприношениями, П.Д. Либеров и А.И. Пузикова предположили, что известные по Геродоту обычаи скифов брать в трофей головы врагов «проникли и к лесостепным племенам» [7, л. 572; 20, с. 79; 21, л. 70]. Дополнительно А.И. Пузикова соотнесла жертву с неким земледельческим божеством, чей образ, по ее мнению, представляла найденная поодаль черепов антропоморфная поделка из камня [21, л. 295].

Во второй половине 1980-х гг. антропологические материалы были открыты еще на трех укрепленных поселениях.

Один из этих памятников - раскапывавшееся экспедицией Воронежского пединститута городище V-III вв. до н. э. у хут. Мостище. На дне одного из его рвов были разбросаны части детского скелета, которые В.Д. Березуцкий и А.Т. Синюк интерпретировали как жертву, возможно строительную [30, c. 101]. Кроме того, в слое находились обломки черепа другого ребенка [28]. Заметим, что на городище обнаружены еще и пять погребений [30, с. 150-152]. Однако к разрозненным останкам они отношения не имеют, поскольку представляют собой небольшой грунтовый могильник рубежа VI-V вв. до н. э., оказавшийся на территории более позднего поселения [23, с. 107].

Некоторое количество человеческих костей найдено скифо-сарматским отрядом экспедиции Воронежского госуниверситета на городище VI-III вв. до н. э. у с. Пекшево. Череп человека лежал у основания оборонительной стены раннескифского времени, располагавшейся по краю мыса. Руководивший раскопками А.П. Медведев счел его закладной жертвой [9, л. 33, прим. 6]. В районе той же стены размещались обломки не менее четырех черепов, в одной из хозяйственных ям - часть свода еще одного черепа, а в культурном слое - фрагмент верхней челюсти другого [10, л. 23; 9, л. 28]. Их происхож- дение А.П. Медведев объяснил военным столкновением [12, с. 84].

Уникальная ситуация была выявлена другим университетским отрядом на городище IV-III вв. до н. э. в г. Семилуки. Там исследовано полтора десятка в основном коллективных захоронений, зачастую содержавших и разрозненные человеческие останки $[17 ; 18 ; 25]$. В погребальных комплексах размещались 50 полных скелетов и отдельные кости еще около 30 индивидов. Те и другие принадлежали людям разного пола и возраста, преимущественно детям и подросткам [24, табл. 1].

По нашему предположению, этот неординарный могильник возник на территории городища в рамках особой погребальной практики, возможно связанной с необычными обстоятельствами массовой гибели местных жителей [19; 25]. Однако А.П. Медведев считает, что в строительных котлованах захоронены, в спешке и по сокращенной обрядности, люди, погибшие при штурме крепости [12, c. 145-152]. Соответственно, и отдельные кости оказались в погребениях, по его мнению, также по воле случая: туда собрали вовремя незахороненные останки [12, с. 148, прим. 3].

Установлено, что подхоронения совершались спустя значительное время после возникновения погребения. Это прослежено по стратиграфии одного из комплексов [25, с. 160 161]. Причем черепа, их обломки и другие кости людей попали в землю вместе с частями туш животных. Их размещали не просто в перекопах верха заполнения погребений, но, возможно, в каких-то более сложных сооружениях. Костям неоднократно сопутствовали следы огня. Скорее всего, разрозненные останки людей и животных следует рассматривать как составную часть жертвенных комплексов, имевших отношение к некоему постпогребальному ритуалу.

Свидетельства обрядовых действий над захоронениями, продолжавшихся достаточно долго, были выявлены, в частности, в постройке, содержавшей скелеты трех человек [17, c. 86-89]. Верх ее котлована заполняли три слоя почвы, в основании каждого из которых располагались очаги-кострища, в плане отчасти перекрывавшие друг друга. Возле среднего очага находились части скелета собаки и заполненное мелом днище сосуда. Выше- 
лежащий почвенный слой, насыщенный золой и обожженной глиной, содержал многочисленные кости животных и обломки керамики, а также женский череп.

С тем же постпогребальным ритуалом, надо полагать, связаны и человеческие останки, размещавшиеся вперемешку с костями животных в другой необычной по конфигурации постройке [18, с. 16-17]. От сооружения сохранился котлован грушевидных очертаний размером $9,5 \times 6,8$ м и глубиной в материке до 1 м. В его расширенной части имелось два скопления костей животных, включавших по четыре человеческих черепа. Еще одно скопление с четырьмя черепами и другими костями людей располагалось в самой глубокой из трех ям, вырытых в дне котлована (рис. 2, 2).

Постройка содержала останки не менее 13 индивидов разного пола и возраста (половина - дети). Из ее заполнения происходят многочисленные фрагменты лепной керамики и несколько предметов, в том числе железный наконечник стрелы. Своеобразная, не имеющая аналогов конструкция и специфическое содержимое позволяют полагать, что данное помещение имело сугубо культовое назначение.

Помимо этого сооружения, отдельные человеческие кости обнаружены в шести углубленных в материк ямах, внешне неотличимых от хозяйственных. Похоже, что и в них целенаправленно захоранивались останки людей и животных в сопровождении битой посуды и огня.

Так, пять человеческих костей вместе с большим количеством костей животных найдены в яме 47. Многочисленные остеологические материалы, кость человека и много фрагментов керамики обнаружены в яме 48 . $\mathrm{B}$ ее заполнении имелась прослойка обожженной глины, а дно было обмазано глиной. Поверх обмазки зафиксирована угольно-золистая прослойка, выше которой располагались развалы трех горшков. Многочисленные костные и керамические материалы также встречены в яме 78 и в слое над ней. Верх заполнения этого сооружения перекрывала прослойка золы, а на дне лежала сильно разрушенная тазовая кость человека.

Немногим более десятка человеческих костей найдены в городищенском слое, как правило, неподалеку от погребений либо у края мысовой площадки.

Кроме того, бедренная кость женщины была обнаружена на дне внешнего рва [22, c. 206]. Этот ров был засыпан в древности при перестройке фортификаций. Следовательно, человеческие останки на городище накапливались с самого начала его существования.

По количеству антропологических материалов Семилукское городище остается пока непревзойденным. Тем не менее общий объем находок заметно увеличился в результате недавних раскопок еще пяти памятников $\mathrm{V}-$ III вв. до н. э.

Раннеславянская экспедиция Института археологии РАН на территории многослойного поселения 19 у с. Ксизово обнаружила яму, содержавшую берцовую и голенную кости, останки животных, камень-курант зернотерки и два железных наконечника стрел [16, с. 192]. Бытовых остатков скифской эпохи на поселении найдено немного, но на его территории размещались грунтовые погребения этого времени. Все же, с учетом приведенных выше аналогий, яму следует рассматривать в контексте поселения, нежели могильника.

Отряд экспедиции Воронежского педуниверситета обнаружил обломки плечевой и теменной костей двух индивидов 35-45 и 3040 лет в небольшом раскопе на городище у с. Устье $[13$, с. 360$]$.

Тем же отрядом найдены кости пяти человек на поселении 2 у хут. Титчиха [14, с. 80]. Обломки черепов двух детей возрастом до 2 лет и нижней челюсти мужчины 35-45 лет были встречены в слое, а фрагмент теменной кости и два обломка глазницы, принадлежавшие ребенку возрастом 6-18 месяцев и другому постарше, лежали на дне углубленного в материк погреба.

Белгородская экспедиция нашла фалангу пальца при раскопках оборонительной линии городища 2 у с. Стрелица [29, с. 174].

Неординарный комплекс открыт в 2016 г. совместной экспедицией Воронежского педуниверситета и Фонда научного краеведения Липецкой области на городище у с. Верхнее Казачье. Это глубокий колодец, в заполнении которого лежали скелеты трех сброшенных мужчин. Выше них располагал- 
ся костяк мужчины возрастом около 50 лет без черепа, рук и отчасти ног (рис. 2, 3). Отдельно были найдены кости голени и нижняя челюсть, возможно, того же индивида. Вверху заполнения колодца имелись две просевшие вниз прослойки глины и обожженной почвы, которые показывают наличие площадки, предназначавшейся, надо полагать, для неких обрядовых действ.

По существу, данный погребально-жертвенный комплекс представляет собой близкую аналогию семилукским захоронениям ${ }^{4}$. Неудивительно, что и на этом городище в слое попадались человеческие кости, а именно: ключицы мужчин 30-39 и 35-49 лет, обломок мужской тазовой кости, фрагмент бедренной кости мужчины старше 40 лет, принадлежавшие разным индивидам кости ступни и кисти, шейный позвонок, часть нижней челюсти.

Анализ. Найденные на донских поселениях кости представлены как целыми, так и фрагментированными экземплярами. Как правило, каждая из них принадлежала отдельному индивиду (см. таблицу). Крайне редко кости находились в сочленении либо в составе неполных скелетов. Судя по имеющимся антропологическим определениям, останки принадлежали мужчинам и женщинам от младенческого до преклонного возраста.

Надо сказать, что специальному антропологическому анализу подверглась лишь часть материалов: М.В. Добровольская, И.К. Решетова и Е.А. Шепель исследовали находки с городищ Верхнее Казачье, Мостище и Семилуки, а также с поселения Титчиха-2. Отметим, что явственных признаков кухонной обработки человеческих останков не обнаружено. Среди костей из семилукских захоронений выявлены экземпляры, подвергшиеся воздействию огня уже после утраты мягких тканей [3, с. 84], а также преднамеренно обработанный фрагмент черепа [31, с. 148]. На обломке черепа с Мостищенского городища были отмечены следы неоднократного переотложения [28, с. 213]. Наблюдения антропологов свидетельствуют о неких манипуляциях с костными остатками, но, к сожалению, не проливают свет на причины их появления на поселениях.

Вообще-то, проблема происхождения поселенческих антропологических материалов касается всей Лесостепной Скифии. Исследователи по-разному трактуют находки человеческих костей [26, с. 109; 27]: одни - как свидетельство бытовой или культовой андрофагии, другие - как остатки жертвоприношений, третьи - как следы вооруженных столкновений, наконец, четвертые - как следствие погребальной практики выставления трупов.

Разумеется, любая из этих теорий не может быть универсальной в силу многообразия возможных причин формирования имеющейся археологической ситуации. Тем не менее некую доминанту можно попытаться определить исходя из установленных фактов.

Вряд ли останки имеют отношение к бытовому или ритуальному каннибализму, даже те, что происходят из мусорных отложений слоя или заполнения рвов. В противном случае в отходах оказалось бы не одна-две, а гораздо больше частей скелета, в том числе со следами кухонной обработки. Для костей

\section{Разрозненные человеческие останки на поселениях скифского времени} в лесостепном Подонье (указано количество индивидов)

\begin{tabular}{|r|l|c|c|c|c|}
\hline $\begin{array}{c}\text { № } \\
\text { п/п }\end{array}$ & \multicolumn{1}{|c|}{ Памятники } & $\begin{array}{c}\text { Вскрытая } \\
\text { площадь, } \\
\text { кв. м }\end{array}$ & $\begin{array}{c}\text { Кости } \\
\text { в слое }\end{array}$ & $\begin{array}{c}\text { Кости в со- } \\
\text { оружениях }\end{array}$ & $\begin{array}{c}\text { Кости в по- } \\
\text { гребальных } \\
\text { комплексах }\end{array}$ \\
\hline 1 & Верхнее Казачье & 1299 & $9(?)$ & - & 1 \\
\hline 2 & Каменка & 200 & 1 & - & - \\
\hline 3 & Ксизово-19 & 2704 & - & $1(?)$ & - \\
\hline 4 & Пекшево & 2676 & 6 & 1 & - \\
\hline 5 & Подгорное-3 & 604 & - & 1 & - \\
\hline 6 & Семилуки & 3774 & более 10 & более 20 & 29 \\
\hline 7 & Устье & 252 & 2 & - & - \\
\hline 8 & Титчиха-2 & 452 & 3 & 2 & - \\
\hline 9 & Мостище & 3747 & 1 & 1 & - \\
\hline 10 & Кировское & 336 & 3 & - & - \\
\hline 11 & Стрелица-2 & 304 & 1 & - & - \\
\hline
\end{tabular}


же, целенаправленно помещенных в те или иные комплексы, следует ожидать если не многочисленности, то какой-то системы отбора. Косвенным аргументом против андрофагии служат и неполные костяки.

Малое число и некомплектность останков не очень-то согласуются и с последствиями военных конфликтов. Кости отнюдь не всегда принадлежали потенциальным воинам, да и встречаются также и на неукрепленных поселениях, где вероятность сражений весьма мала.

В большинстве своем антропологические материалы найдены в контексте, исключающем интерпретацию их в качестве отбросов. Более того, во многих случаях вполне очевидна их важная роль в культовой практике.

Прежде всего это касается черепов, в частности тех, что были обнаружены на Кировском городище. Об облике существовавшего здесь ритуального комплекса можно судить, в общих чертах, по аналогиям, известным на украинских городищах [2, с. 131, 152; 4, с. 3941]. Трудно усомниться в культовом характере и находок на поселении у с. Подгорное.

Вопрос заключается в том, свидетельствуют ли отделенные от туловища головы в пользу существования у земледельцев лесостепи некоего кровавого обряда. Судя по отсутствию при черепах шейных позвонков, насильственная декапитация людей если и производилась, то где-то в другом месте, иначе картина была бы иной [8, с. 175]. Все найденные черепа, нередко уже распавшиеся на куски, были без нижних челюстей, следовательно оказались в тех или иных комплексах уже лишенные мягких тканей. Надо полагать, что в таком же виде, за редчайшими исключениями, попали туда и другие человеческие кости.

Сама выборка перемещенных костей выглядит в целом случайной. Впрочем, черепа и их обломки пользовались определенным предпочтением, надо полагать, вследствие особой сакральности, а возможно и из-за «узнаваемости». Явно хаотичный набор останков показывает, что большую их часть уже невозможно было собрать в местах первоначального размещения. Самая вероятная причина этого - длительное нахождение тел умерших людей в непогребенном состоянии. При этом речь не может идти, как уже отмечалось, о полях сражений, скорее о неких площадках для выставления трупов, существовавших либо на территории самих поселений, либо в их ближайшей округе.

Захоронения разрозненных останков в поселенческих сооружениях, погребальных и хозяйственно-бытовых, открыты повсюду в Лесостепной Скифии (сводку данных см.: [26, табл.]). Судя по всему, манипуляциям с человеческими костями придавалось большое значение в культовой практике оседлого населения этой историко-культурной области.

Результаты. Анализ имеющихся данных убеждает в том, что наиболее вероятной причиной появления на поселениях скифской эпохи разрозненных человеческих костей могла быть погребальная практика, предполагавшая оставление без захоронения на достаточно длительный срок тел умерших людей. Труповыставление известно у многих народов, и вполне допустимо его существование в среде оседлого населения лесостепного Подонья ${ }^{5}$. Такое предположение, на наш взгляд, лучше всего согласуется с выявленной на местных поселениях археологической картиной.

\section{ПРИМЕЧАНИЯ}

${ }^{1}$ Работа подготовлена при финансовой поддержке РФФИ в рамках проекта № 18-09-00230 «Погребальные и культовые практики оседлого населения скифо-сарматской эпохи в лесостепном Подонье».

${ }^{2}$ Речь идет о скифоидных памятниках. На широко представленных в регионе поселениях городецкой культуры такие находки отсутствуют. Единственное пока исключение - человеческие зубы в одной из построек поселения Студеновка-3 [11, с. 82].

${ }^{3}$ В дополнение к ним стоит упомянуть еще городище у хут. Титчиха, на котором есть слой скифского времени. Там в одной из хозяйственных ям был найден череп человека [15, л. 17]. Немногочисленные керамические материалы как будто датируют это сооружение славянской эпохой, что проверить, к сожалению, сейчас невозможно.

${ }^{4}$ Примечательно, что в одном из семилукских погребений тоже был неполный скелет [17, с. 84].

${ }^{5}$ Впрочем, эта похоронная обрядность не была единственной. В регионе известны и грунтовые могильники, использовавшиеся обитателями близлежащих поселений [23]. 


\section{ПРИЛОЖЕНИЕ}

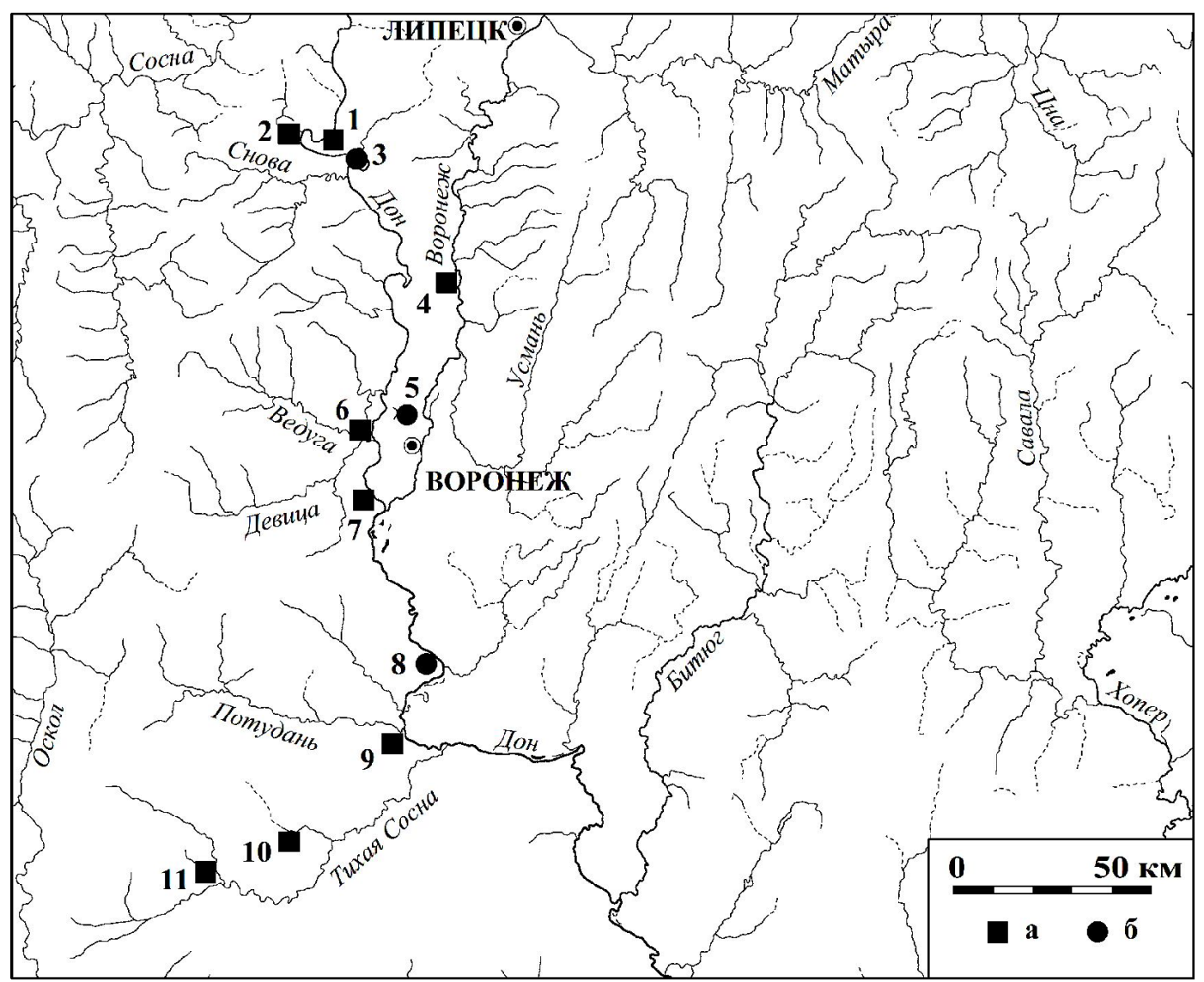

Рис. 1. Городища $(a)$ и неукрепленные поселения (б) скифского времени в лесостепном Подонье, на которых найдены разрозненные человеческие кости:

1 - Верхнее Казачье; 2 - Каменка; 3 - Ксизово-19; 4 - Пекшево; 5 - Подгорное-3; 6 - Семилуки; 7 - Устье; 8 - Титчиха-2; 9 - Мостище; 10 - Кировское; 11 - Стрелица-2

Fig. 1. Hillforts $(a)$ and unfortified settlements $(b)$ of the Scythian Time in the forest-steppe region of the Don Basin, where segmental human bones were found:

1 - Verkhnee Kazachye; 2 - Kamenka; 3 - Ksizovo-19; 4 - Pekshevo; 5 - Podgornoe-3; 6 - Semiluki; 7 - Ustye; 8 - Titchikha-2; 9 - Mostishche; 10 - Kirovskoe; 11 - Strelitsa-2 
Ю.Д. Разуваев. Находки человеческих костей на поселениях скифского времени в лесостепном Подонье
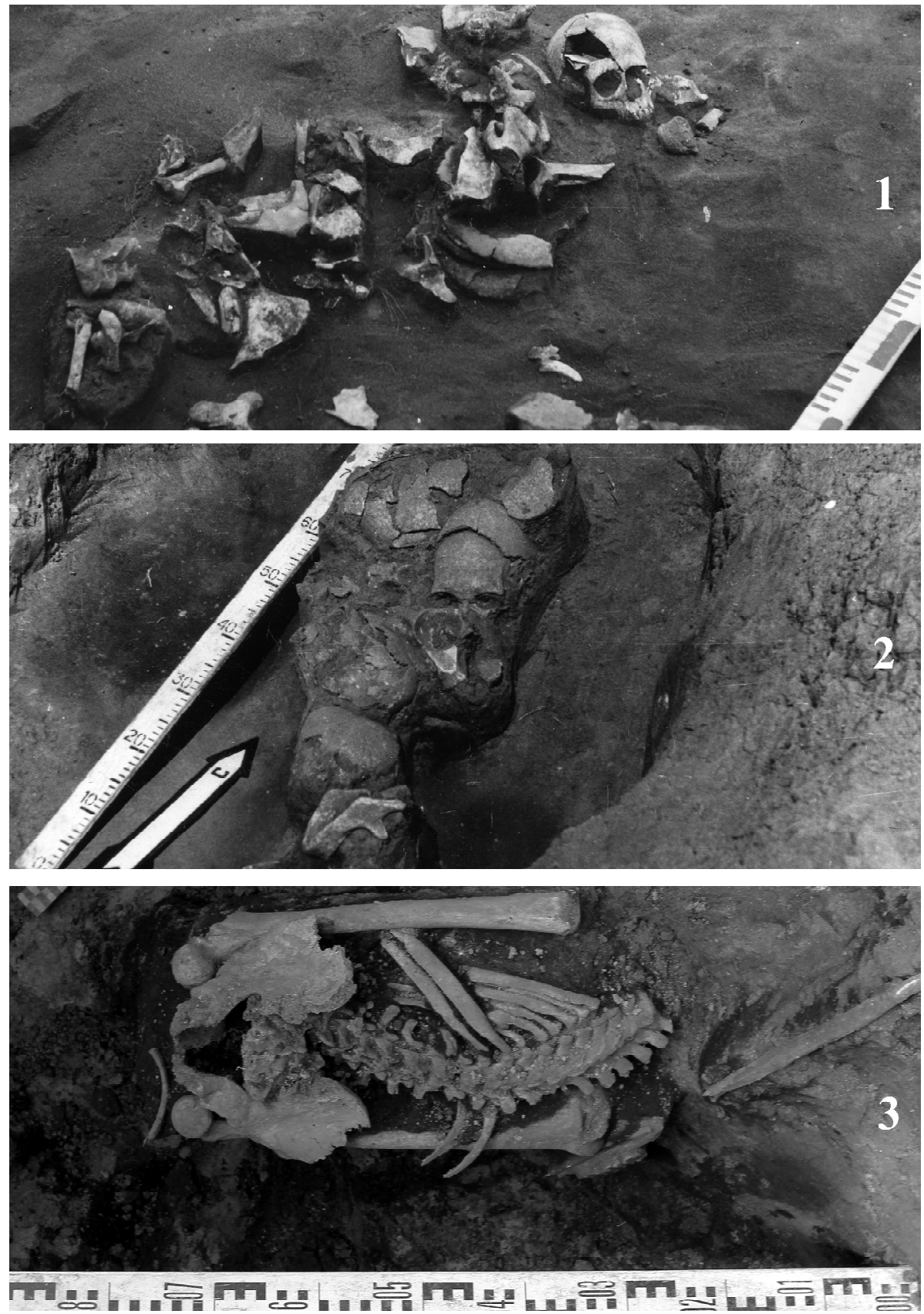

Рис. 2. Человеческие останки на поселениях:

1 - череп на поселении 3 у с. Подгорное; 2 - черепа в постройке на Семилукском городище; 3 - часть скелета в колодце на городище у с. Верхнее Казачье

Fig. 2. Human remains in the settlements:

1 - skull in settlement 3 near the Podgornoe village; 2 - skulls in the construction of the Semiluksky hillfort; 3 - part of the skeleton in the well from the hillfort near the village Verkhnee Kazachye 


\section{СПИСОК ЛИТЕРАТУРЫ}

1. Бирюков, И. Е. Городище скифского времени у с. Каменка на Верхнем Дону / И. Е. Бирюков, Ю. Д. Разуваев // Археологические памятники бассейна Дона / отв. ред. А. Т. Синюк. - Воронеж : Изд-во ВГПУ, 2004. - С. 181-191.

2. Гавриш, П. Я. Племена скіфського часу в лісостепу Дніпровського Лівобережжя (за матеріалами Припсілля) / П. Я. Гавриш. - Полтава : Археологія, 2000.-232 с.

3. Добровольская, М. В. К антропологии населения Среднего Дона в скифское время / М. В. Добровольская // Археология Среднего Дона в скифскую эпоху : Труды Донской (Потуданской) археологической экспедиции ИА РАН, 2001-2003 / отв. ред. В. И. Гуляев. - М. : ИА РАН, 2004. - С. 69-106.

4. Исследования совместной УкраинскоНемецкой археологической экспедиции в 2000 г. / В. Ю. Мурзин [и др.]. - Киев : ИА НАНУ : Нем. науч.-исслед. о-во, 2001. - 72 с.

5. Либеров, П. Д. Отчет о работе Воронежского отряда Лесостепной экспедиции ИИМК АН СССР в 1958 г. / П. Д. Либеров // Архив Института археологии РАН. - Р-1. - № 1726. - 76 л.

6. Либеров, П. Д. Отчет о раскопках в Белгородской, Воронежской областях, произведенных Лесостепной скифской археологической экспедицией в 1965 г. / П. Д. Либеров, А. И. Пузикова, Г. И. Корнюшин // Архив Института археологии РАН. - Р-1. № 3126. -167 л.

7. Либеров, П. Д. Древняя история населения Подонья. [В2 ч. Ч. 2] : дис. ... д-ра ист. наук / П. Д. Либеров. - М., 1971 // Архив Института археологии РАН. - Р-2. - № 2088. - 687 л.

8. Масленников, А. А. «Ифигения на Меотиде» (материалы к обсуждению существования ритуальной декапитации в античном Приазовье) / А. А. Масленников, А. П. Бужилова // Древности Боспора / под ред. А. А. Масленникова, А. А. Завойкина. - М. : ИА РАН, 1999. - Вып. 2. - С. 174-183.

9. Медведев, А. П. Отчет скифо-сарматского отряда археологической экспедиции Воронежского университета о раскопках Пекшевского городища в 1986 г. / А. П. Медведев // Архив Института археологии РАН. - Р-1. - № 11844. - 94 л.

10. Медведев, А. П. Отчет скифо-сарматского отряда археологической экспедиции Воронежского госуниверситета о работах в 1987 г. / А. П. Медведев // Архив Института археологии РАН. - Р-1. № 12056. -80 л.

11. Медведев, А. П. Поселение раннего железного века Студеновка 3 / А. П. Медведев // Археология Доно-Волжского бассейна / отв. ред. А. Т. Синюк. - Воронеж : Изд-во Воронеж. пединститута, 1993. - C. 79-90.
12. Медведев, А. П. Ранний железный век лесостепного Подонья. Археология и этнокультурная история І тысячелетия до н. э. / А. П. Медведев. М. : Наука, 1999. - 160 с.

13. Меркулов, А. Н. Городище скифского времени у с. Устье на Верхнем Дону (исследования 2013 г.) / А. Н. Меркулов // Верхнедонской археологический сборник / отв. ред. А. Н. Бессуднов. - Липецк : Изд-во Липец. госпедуниверситета, 2014. Вып. 6. - С. 359-364.

14. Меркулов, А. Н. Поселение 2 у хут. Титчиха на Среднем Дону (исследования 2016 г.) / А. Н. Меркулов // История: факты и символы. - 2017. № 2 (11). - C. 77-85. - DOI: https://doi.org/10.24888/ 2410-4205-2017-11-2-77-85.

15. Москаленко, А. Н. Отчет об археологических раскопках на Титчихинском городище Лискинского района Воронежской области в 1962 г. / А. Н. Москаленко // Архив Института археологии РАН. - Ф. 1. - Р-1. - № 2474. - 103 л.

16. Обломский, А. М. Грунтовые погребения скифского времени у с. Ксизово на Верхнем Дону / А. М. Обломский, Ю. Д. Разуваев // Краткие сообщения Института археологии. - 2013. - Вып. 231. С. 183-195.

17. Пряхин, А. Д. Погребения на Семилукском городище позднескифского времени (раскопки 1986 г.) / А. Д. Пряхин, Ю. Д. Разуваев // Археологические памятники раннего железного века ОкскоДонского междуречья / отв. ред. В. П. Челяпов. Рязань : НПЦ по охране и использ. памятников истории и культуры Рязан. обл., 1993. - С. 74-94.

18. Пряхин, А. Д. Погребения на Семилукском городище позднескифского времени (раскопки 1987-1990 гг.) / А. Д. Пряхин, Ю. Д. Разуваев // Древние памятники Окского бассейна / отв. ред. В. П. Челяпов. - Рязань : НПЦ по охране и использ. памятников истории и культуры Рязан. обл., 1993. C. $13-30$.

19. Пряхин, А. Д. К интерпретации захоронений на Семилукском городище скифского времени / А. Д. Пряхин, Ю. Д. Разуваев // Скифы и сарматы в VIII-III вв. до н. э.: палеоэкология, антропология и археология / отв. ред. В. И. Гуляев, В. С. Ольховский. - М. : Ин-т археологии РАН, 2000. - C. 249-257.

20. Пузикова, А. И. Поселения Среднего Дона / А. И. Пузикова // Население Среднего Дона в скифское время / отв. ред. А. П. Смирнов. - М. : Наука, 1969. - С. 41-81. - (Материалы и исследования по археологии СССР ; № 151).

21. Пузикова, А. И. Культура оседлых племен Правобережья Среднего Дона в скифское время : дис. ... канд. ист. наук / А. И. Пузикова. - М., 1971 // Архив Института археологии РАН. - Р-2. № 2087. -338 л. 
22. Разуваев, Ю. Д. Результаты исследований оборонительных сооружений Семилукского городища в 2012 г. / Ю. Д. Разуваев // Восточноевропейские древности / отв. ред. А. Н. Ворошилов. - Воронеж : Науч. кн., 2013. - С. 196-211. - (Вестник Острогожского историко-художественного музея им. И.Н. Крамского ; вып. 3).

23. Разуваев, Ю. Д. О грунтовых могильниках скифского времени в донской лесостепи / Ю. Д. Разуваев // Вестник Воронежского государственного университета. Серия: История. Политология. Социология. - 2014. - № 2. - С. 103-111.

24. Разуваев, Ю. Д. Могильник на Семилукском городище скифского времени в свете новых исследований / Ю. Д. Разуваев // Вестник Воронежского государственного университета. Серия: История. Политология. Социология. -2015. - № 2. C. $98-107$.

25. Разуваев, Ю. Д. Новый погребальный комплекс скифского времени на Семилукском городище / Ю. Д. Разуваев // Краткие сообщения Института археологии. - 2015. - Вып. 231. - С. 157-166.

26. Разуваев, Ю. Д. Захоронения и останки людей на поселениях Лесостепной Скифии: состояние источников / Ю. Д. Разуваев // Российская археология. -2016. - № 3. - С. 102-120.

27. Разуваев, Ю. Д. Разрозненные человеческие останки на поселениях Лесостепной Скифии: обзор интерпретационных подходов / Ю. Д. Разуваев // Вестник Томского государственного университета. [Серия]: История. - 2018. - № 55. - С. 142147. - DOI: https://doi.org/10.17233/19988613/55/21.

28. Решетова, И. К. Описание фрагмента черепа из культурного слоя Мостищенского городища / И. К. Решетова, М. В. Добровольская // Восточноевропейские древности / отв. ред. А. Н. Ворошилов. - Воронеж : Науч. кн., 2013. - С. 212-215. - (Вестник Острогожского историко-художественного музея им. И.Н. Крамского ; вып. 3).

29. Сарапулкина, Т. В. Оборонительные сооружения Стрелецкого городища-2 скифского времени / Т. В. Сарапулкина, В. А. Сарапулкин, А. А. Божко // Восточноевропейские древности / отв. ред. Ю. Д. Разуваев. - Воронеж : Науч. кн., 2012. С. 170-178.-(Вестник Острогожского историко-художественного музея им.И.Н. Крамского ; вып. 2).

30. Синюк, А. Т. Мостищенский комплекс древних памятников (эпоха бронзы - ранний железный век) / А. Т. Синюк, В. Д. Березуцкий. - Воронеж : Изд-во ВГПУ, 2001. - 192 с.

31. Шепель, Е. А. Население Семилукского городища скифского времени (по антропологическим материалам) / Е. А. Шепель // Археологические памятники Восточной Европы / отв. ред. А. Т. Синюк. Воронеж : Изд-во Воронеж. госпедуниверситета, 2002.-C. 145-156.
32. Шульгин, А. Н. Исследования в северо-западном углу Орловской губернии / А. Н. Шульгин // Труды Орловской ученой архивной комиссии за 1904 и 1905 гг. -Орел : [б. и.], 1906. - С. 91-115.

\section{REFERENCES}

1. Biryukov I.E., Razuvaev Yu.D. Gorodishche skifskogo vremeni u s. Kamenka na Verkhnem Donu [The Fortified Settlement of the Scythian Time near the Kamenka Village on the Upper Don]. Sinyuk A.T., ed. Arkheologicheskie pamyatniki basseyna Dona [Archaeological Sites of the Don Basin]. Voronezh, Izd-vo VGPU, 2004, pp.181-191.

2. Gavrish P.Ya. Plemena skifskogo chasu v lisostepu Dniprovskogo Livoberezhzhya (za materialami Pripsillya) [Tribes of the Scythian Time in the Forest-Steppe Dnieper Left Bank (Based on the Materials of the Psel Basin)]. Poltava, Arkheologiya Publ., 2000. 232 p.

3. Dobrovolskaya M.V. K antropologii naseleniya Srednego Dona v skifskoe vremya [To the Anthropology of the Population of the Middle Don in the Scythian Time]. Gulyaev V.I., ed. Arkheologiya Srednego Dona v skifskuyu epokhu: Trudy Donskoy (Potudanskoy) arkheologicheskoy ekspeditsii IA RAN, 2001-2003 [Archaeology of the Northern Don in the Scythian Epoch: Works of Don (Potudan) Archaeological Expedition, RAS, 2001-2003]. Moscow, Izd-vo IA RAN, 2004, pp. 69-106.

4. Murzin V.Yu., Rolle R., Gerts V., Skoryy S.A., Makhortykh S.V., Belozor V.P. Issledovaniya sovmestnoy Ukrainsko-Nemetskoy arkheologicheskoy ekspeditsii v $2000 \mathrm{~g}$. [Research of the Joint Ukranian-German Archaeological Expedition in 2000]. Kiev, IA NANU; Nem. nauch.-issled. o-vo Publ., 2001. 72 p.

5. Liberov P.D. Otchet o rabote Voronezhskogo otryada Lesostepnoy ekspeditsii IIMK AN SSSR v $1958 \mathrm{~g}$. [Report on the work of Voronezh group of Forest-steppe expedi-tion IIMK AN SSSR in 1958]. Arkhiv Instituta arkheologii RAN [Archive of Institute of Archeology of the Russian Academy of Sciences], R-1, no. $1726.76 \mathrm{p}$.

6. Liberov P.D., Puzikova A.I., Kornyushin G.I. Otchet o raskopkakh v Belgorodskoy, Voronezhskoy oblastyakh, proizvedennykh Lesostepnoy skifskoy arkheologicheskoy ekspeditsiey v 1965 g. [Report on Excavations in the Belgorod and Voronezh Regions Performed by the Forest-Steppe Scythian Archaeological Expedition in 1965]. Arkhiv Instituta arkheologii RAN [Archive of Institute of Archeology of the Russian Academy of Sciences], R-1, no. 3126. 167 p.

7. Liberov P.D. Drevnyaya istoriya naseleniya Podonya. V 2 ch. Ch. 2: dis. ... d-ra ist. nauk [Ancient History of the Don Basin Population. In 2 Parts. Part 2. Dr. hist. sci. diss.]. Moscow, 1971. Arkhiv Instituta 
arkheologii RAN [Archive of Institute of Archeology of the Russian Academy of Sciences], R-2, no. 2088. 687 p.

8. Maslennikov A.A., Buzhilova A.P. «Ifigeniya na Meotide» (materialy k obsuzhdeniyu sushchestvovaniya ritualnoy dekapitatsii v antichnom Priazovye) [Iphigenia on Meotida (Materials for Discussion of the Ritual Decapitation in Antique Priazovye]. Maslennikov A.A., Zavoykin A.A., eds. Drevnosti Bospora [Bospor's Antiquities]. Moscow, Izd-vo IA RAN, 1999, iss. 2, pp. 174-183.

9. Medvedev A.P. Otchet skifo-sarmatskogo otryada arkheologicheskoy ekspeditsii Voronezhskogo universiteta o raskopkakh Pekshevskogo gorodishcha v 1986 g. [Report of Skithian-Sarmatian Group of Archaeological Expedition of the Voronezh State University on Excavations in the Pekshevsky Hillfort in 1986]. Arkhiv Instituta arkheologii RAN [Archive of Institute of Archeology of the Russian Academy of Sciences], R-1, no. 11844. 94 p.

10. Medvedev A.P. Otchet skifo-sarmatskogo otryada arkheologicheskoy ekspeditsii Voronezhskogo gosuniversiteta o rabotakh v $1987 \mathrm{~g}$. [Report of Skithian-Sarmatian Group of Archaeological Expedition of the Voronezh State University on Works in 1987]. Arkhiv Instituta arkheologii RAN [Archive of Institute of Archeology of the Russian Academy of Sciences], R-1, no. 12056.80 p.

11. Medvedev A.P. Poselenie rannego zheleznogo veka Studenovka 3 [The Settlement Studenovka 3 of the Early Iron Age]. Sinyuk A.T., ed. Arkheologiya Dono-Volzhskogo basseyna [Archeology of the Don-Volga Basin]. Voronezh, Izd-vo VGPU, 1993, pp. 79-90.

12. Medvedev A.P. Ranniy zheleznyy vek lesostepnogo Podonya. Arkheologiya $i$ etnokulturnaya istoriya I tysyacheletiya do n. e. [The Early Iron Age of the Forest-Steppe Don Region. Archaeology and Ethnocultural History of the $1^{\text {st }}$ Millennium BC]. Moscow, Nauka Publ., 1999. 160 p.

13. Merkulov A.N. Gorodishche skifskogo vremeni u s. Ustye na Verkhnem Donu (issledovaniya 2013 g.) [Fortified Settlement of the Scythian Time near the Village Ustye on the Upper Don (Research of 2013)]. Bessudnov A.N., ed. Verkhnedonskoy arkheologicheskiy sbornik [Upper Don Archaeological Collection]. Lipetsk, Izd-voLGPU, 2014, iss. 6, pp. 359-364.

14. Merkulov A.N. Poselenie $2 \mathrm{u}$ khut. Titchikha na Srednem Donu (issledovaniya 2016 g.) [Settlement 2 at the Titchikha Farmstead on the Middle Don (Research of 2016)]. Istoriya: fakty i simvoly [History: Facts and Symbols], 2017, no. 2 (11), pp. 77-85. DOI: https://doi.org/10.24888/2410-4205-2017-11-2-77-85.

15. MoskalenkoA.N. Otchet ob arkheologicheskikh raskopkakh na Titchikhinskom gorodishche Liskinskogo rayona Voronezhskoy oblasti v 1962 g. [Report on Archaeological Excavations in the Titchikha Ancient
Settlement of the Liskinsky District of the Voronezh Region in 1962]. Arkhiv Instituta arkheologii RAN [Archive of Institute of Archeology of the Russian Academy of Sciences], R-1, no. 2474. 103 p.

16. Oblomskiy A.M., Razuvaev Yu.D. Gruntovye pogrebeniya skifskogo vremeni u s. Ksizovo na Verkhnem Donu [Ground Burials of the Scythian Period near the Village Ksizovo on the Upper Don]. Kratkie soobshcheniya Instituta arkheologii [Short Messages of Institute of Archaeology], 2013, iss. 231, pp. 183-195.

17. Pryakhin A.D., Razuvaev Yu.D. Pogrebeniya na Semilukskom gorodishche pozdneskifskogo vremeni (raskopki 1986 g.) [Burials at the Semilukskoe Hillfort of the Late Scythian Time (Excavations of 1986)]. Chelyapov V.P., ed. Arkheologicheskie pamyatniki rannego zheleznogo veka OkskoDonskogo mezhdurechya [Archaeological Sites of the Early Iron Age of the Oka-Don Interfluve]. Ryazan, The research and production center on protection and use of historical and cultural monuments of the Ryazan region, 1993, pp. 74-94.

18. Pryakhin A.D., Razuvaev Yu.D. Pogrebeniya na Semilukskom gorodishche pozdneskifskogo vremeni (raskopki 1987-1990 gg.) [Burials at the Semilukskoe Hillfort of the Late Scythian Time (Excavations of 1987-1990)]. Chelyapov V.P., ed. Drevnie pamyatniki Okskogo basseyna [Ancient Sites of the Oka Basin]. Ryazan, The research and production center on protection and use of historical and cultural monuments of the Ryazan region, 1993, pp. 13-30.

19. Pryakhin A.D., Razuvaev Yu.D. K interpretatsii zakhoroneniy na Semilukskom gorodishche skifskogo vremeni [To the Interpretation of Burials at the Semilukskoe Hillfort of the Scythian Time]. Gulyaev V.I., Olkhovskiy V.S., eds. Skify $i$ sarmaty $v$ VIII-III vv. do n. e.: paleoekologiya, antropologiya $i$ arkheologiya [Scythians and Sarmatians in the $8^{\text {th }}-$ $3^{\text {rd }}$ cc. BC: Paleoecology, Anthropology and Archaeology]. Moscow, Izd-vo IA RAN, 2000, pp. 249-257.

20. Puzikova A.I. Poseleniya Srednego Dona [Settlements of the Middle Don]. Smirnov A.P., ed. Naselenie Srednego Dona v skifskoe vremya [The Population of the Middle Don in Scythian Time]. Moscow, Nauka Pub., 1969, pp. 41-81. (Materials and research on archaeology of the USSR; no. 151).

21. Puzikova A.I. Kultura osedlykh plemen Pravoberezhya Srednego Dona v skifskoe vremya: dis. ... kand. ist. nauk [Culture of Settled Tribes of the Middle Don Right Bank in the Scythian Time. Cand. hist. sci. diss.]. Moscow, 1971. Arkhiv Instituta arkheologii RAN [Archive of Institute of Archeology of the Russian Academy of Sciences], R-2, no. 2087. $338 \mathrm{p}$. 
22. Razuvaev Yu.D. Rezultaty issledovaniy oboronitelnykh sooruzheniy Semilukskogo gorodishcha v $2012 \mathrm{~g}$. [The Results of Investigating Defensive Constructions of the Semilukskoe Hillfort in 2012]. Voroshilov A.N., ed. Vostochnoevropeyskie drevnosti [Eastern European Antiquities]. Voronezh, Nauchnaya kniga Publ., 2013, pp. 196-211. (Vestnik Ostrogozhskogo istoriko-khudozhestvennogo muzeya im. I.N. Kramskogo; iss. 3).

23. Razuvaev Yu.D. O gruntovykh mogilnikakh skifskogo vremeni $\mathrm{v}$ donskoy lesostepi [About Burial Grounds of the Scythian Time in the Don Forest-Steppe]. Vestnik Voronezhskogo gosudarstvennogo universiteta. Seriya: Istoriya. Politologiya. Sotsiologiya [Vestnik of Voronezh State University. Series: History. Political science. Sociology], 2014, no. 2, pp. 103-111.

24. Razuvaev Yu.D. Mogilnik na Semilukskom gorodishche skifskogo vremeni $\mathrm{v}$ svete novykh issledovaniy [Burial Ground at the Semilukskye Hillfort of the Scythian Time in the Light of New Research]. Vestnik Voronezhskogo gosudarstvennogo universiteta. Seriya: Istoriya. Politologiya. Sotsiologiya [Vestnik of Voronezh State University. Series: History. Political science. Sociology], 2015, no. 2, pp. 98-107.

25. Razuvaev Yu.D. Novyy pogrebalnyy kompleks skifskogo vremeni na Semilukskom gorodishche [New Burial Complex of the Scythian Time at the Semilukskoe Hillfort]. Kratkie soobshcheniya Instituta arkheologii [Short Messages of Institute of Archaeology], 2015, iss. 231, pp. 157-166.

26. Razuvaev Yu.D. Zakhoroneniya i ostanki lyudey na poseleniyakh Lesostepnoy Skifii: sostoyanie istochnikov [Burials and Human Remains in Settlements of Forest-Steppe Scythia: State of Sources]. Rossiyskaya arkheologiya [Russian Archaeology], 2016, no. 3, pp. 102-120.

27. Razuvaev Yu.D. Razroznennye chelovecheskie ostanki na poseleniyakh Lesostepnoy Skifii: obzor interpretatsionnyh podkhodov [Separate Human Remains in the Settlements of Forest-Steppe Scythia:
Review of Interpretative Approaches]. Vestnik Tomskogo gosudarstvennogo universiteta. [Seriya]: Istoriya [Bulletin of the Tomsk State University. History], 2018, no. 55, pp. 142-147. DOI: https://doi. org/10.17233/19988613/55/21.

28. Reshetova I.K., Dobrovolskaya M.V. Opisanie fragmenta cherepa iz kulturnogo sloya Mostishchenskogo gorodishcha [The Description of the Skull Fragment from the Cultural Layer of the Mostishchenskoe Hillfort]. Voroshilov A.N., ed. Vostochnoevropeyskie drevnosti [East European Antiquities]. Voronezh, Nauchnaya kniga Publ., 2013, pp. 212-215. (Vestnik Ostrogozhskogo istorikokhudozhestvennogo muzeya im. I.N. Kramskogo; iss. 3).

29. Sarapulkina T.V., Sarapulkin V.A., Bozhko A.A. Oboronitelnye sooruzheniya Streletskogo gorodishcha2 skifskogo vremeni [Fortification of the Streletsky Hillfort-2 of the Scythian Time]. Razuvaev Yu.D., ed. Vostochnoevropeyskie drevnosti [East European Antiquities]. Voronezh, Nauchnaa kniga Publ., 2012, pp. 170-178. (Vestnik Ostrogozhskogo istorikokhudozhestvennogo muzeya im. I.N. Kramskogo; iss. 2).

30. Sinyuk A.T., Berezutskiy V.D. Mostishchenskiy kompleks drevnikh pamyatnikov (epokha bronzy - ranniy zheleznyy vek) [Mostishchenskiy Complex of Ancient Monuments (the Bronze Age the Early Iron Age)]. Voronezh, Izd-vo VGPU, 2001. $192 \mathrm{p}$.

31. Shepel E.A. Naselenie Semilukskogo gorodishcha skifskogo vremeni (po antropologicheskim materialam) [Population of the Semilukskoe Hillfort of the Scythian Time]. Sinyuk A.T., ed. Arkheologicheskie pamyatniki Vostochnoy Evropy [Archaeological Sites of Eastern Europe]. Voronezh, Izd-vo VGPU, 2002, pp. 145-156.

32. Shulgin A.N. Issledovaniya $\mathrm{v}$ severozapadnom uglu Orlovskoy gubernii [Research in a Northwest Corner of the Orel Province]. Trudy Orlovskoy uchenoy arkhivnoy komissii za 1904 i $1905 \mathrm{gg}$. [Works of the Orel Scientific Archival Commission for 1904 and 1905]. Orel, 1906, pp. 91-115.

\section{Information about the Author}

Yuriy D. Razuvaev, Candidate of Sciences (History), Associate Professor of Department of History of Russia, Voronezh State Pedagogical University, Lenina St., 86, 394043 Voronezh, Russian Federation, razuvaevyd@mail.ru, https://orcid.org/0000-0003-4865-3206

\section{Информация об авторе}

Юрий Дмитриевич Разуваев, кандидат исторических наук, доцент кафедры истории России, Воронежский государственный педагогический университет, ул. Ленина, 86, 394043 г. Воронеж, Российская Федерация, razuvaevyd@mail.ru, https://orcid.org/0000-0003-4865-3206 